\title{
Productive Teacher Job Satisfaction in Terms of the Indirect Influence of Organizational Climate Through the Management of Infrastructure and Organizational Citizenship Behavior
}

\author{
Soparidah*, R Madhakomala and I Hanavi \\ Postgraduate Department, Jakarta State University, Jakarta, Indonesia \\ *Corresponding author. Email: soparidahjasmine.02@gmail.com
}

\begin{abstract}
Productive teacher job satisfaction in private vocational high school needs to be analyzed the indirect variables that influence it. This study analyzes the indirect effect of organizational climate on job satisfaction through organizational citizenship behavior and infrastructure management. The research sample was 270 productive teachers from 87 private vocational high schools in Jakarta, Indonesia. The research approach is quantitative with a path analysis method. The result is that organizational climate has an indirect effect on the job satisfaction of productive teachers by 0.358 if it is through organizational citizenship behavior. Meanwhile, the organizational climate has an indirect effect on the job satisfaction of productive teachers of 0.062. So there needs to be an effort from the private vocational high school, especially in Jakarta to create a conducive organizational climate so that teachers feel part of the school community.
\end{abstract}

Keywords: Job satisfaction, productive teachers, organizational climate, management of facilities

\section{INTRODUCTION}

Job satisfaction is an individual's expression of personal wellbeing associated with doing the job assigned [1]. Job satisfaction is directly influenced by organizational climate [2], [3]. Organizational climate has been a variable that has been researched quite recently as a variable predictor of job satisfaction. It is necessary to develop a concept that examines other variables as the intervening variable of organizational climate on job satisfaction. This is necessary to know what variables can indirectly be the link between organizational climate and job satisfaction. There is one behavior of members in an organization that can benefit the company because they feel that they are part of the organization known as Organizational Citizenship Behavior (OCB) [4]. This behavior is an ideal organizational behavior that many experts discuss because it can support productivity in the company. The results showed a very significant relationship between organizational climate and OCB [5].

There are research findings that a strong positive organizational climate will create high OCB, thereby increasing job satisfaction [6]. This opinion is corroborated by the results of other studies that prove that organizational climate and OCB have positive and very significant values [7]. So that it can be concluded that organizational climate is the perception of organizational members (individually and in groups) and those who are constantly in touch with the organization (for example suppliers, consumers, consultants, and contractors) regarding what is or happens in the organization's internal environment regularly, which affects attitudes and organizational behavior as well as organizational performance which in turn will determine the performance of the organization itself [8]. This means that the more conducive the organizational climate in an organization will be followed by a high OCB which can then automatically increase job satisfaction. Based on this, it is assumed that the organizational climate has an indirect effect on job satisfaction through OCB.

Satisfaction occurs when individual needs are met and is related to the degree of likes and dislikes associated with employees; is a general attitude that employees have that is closely related to the rewards they believe they will receive after making a sacrifice [9]. Job Satisfaction is a 
positive feeling in a job, which is the impact/evaluation result of various aspects of the job [10].

According to Luthans (2011) organizational climate is an overall "feeling" that is conveyed by the physical layout, the way participants interact, and the way members of the organization conduct themselves with customers or other outsiders. This means that climate is how members feel at work which is influenced by the internal environment of the organization, influences their behavior, and is a characteristic of the organization. One of the internal environment is influenced by the management of facilities and infrastructure [12]. Therefore, if the climate in an organization is conducive and positive, it will influence the management of facilities and infrastructure effectively [13]. Therefore it is necessary to do empirical research on the indirect effect of organizational climate through the management of facilities and infrastructure on job satisfaction.

Vocational high school (VHS), which is one of the formal educational institutions that produce ready-to-work graduates, is still less attractive to the community [14]. When compared to course institutions that both teach skills, VHS is considered superior because formal education is still recognized in the world of work [15]. However, there are still quite a lot of VHS students who lack the motivation to learn at school [16]. This is because teacher quality is one of the keys to success in the education process. After all, VHS teachers, whereas in VHS there are teachers in the field of expertise who are known as productive teachers who specifically teach a certain skill [17].

Problems that arise regarding the low job satisfaction of productive teachers [18]. This finding is reinforced by the results of simple observations made by researchers when communicating with productive VHS teachers in East Jakarta. Complaints that were submitted ranged from the unsupportive working climate, often given additional assignments from the principal, naughty students to inadequate facilities. This is a natural thing because private schools are not fully supported by the government, especially in terms of providing facilities and infrastructure.

The low job satisfaction of productive teachers is thought to be caused by organizational climate, management of facilities and infrastructure, and OCB [4], [6], [7], [19]. This is because until now there has been no empirical research on the job satisfaction of productive teachers in terms of organizational climate, management of facilities and infrastructure, and OCB. Classrooms and schools become effective when quality people are recruited to teach, and the workplace is organized to energized teachers and reward accomplishments [20]. One of the qualified teachers has high OCB while the work environment is one of the indicators is the management of facilities and infrastructure and a conducive organizational climate [21].

\section{METHODOLOGY}

This research used a qualitative approach with a path analysis method. The data collection technique used a questionnaire with 5 answer choices for the variable job satisfaction, organizational climate, OCB, and school facility management. The data in this study amounted to 270 productive teachers from 87 Private Vocational High Schools (PVHS) located in DKI Jakarta. The sampling technique used purposive sampling with consideration of sampling from many populations with productive teachers in PVHS [14].

The path analysis model uses exogenous and endogenous variables. Exogenous variables have a direct or indirect effect on endogenous variables. Meanwhile, endogenous variables are variables that can influence other endogenous variables [14]. The research hypothesis is:

H1: Organizational climate has an indirect effect on job satisfaction through Organizational Citizenship Behavior

$\mathrm{H}$ 2: Organizational climate has an indirect effect on job satisfaction through Facility and Infrastructure Management

\section{RESULTS AND DISCUSSION}

The results of the calculation of path analysis are divided into 2 models, namely model 1 calculating the coefficient value of organizational climate, management of facilities and infrastructure, and OCB on job satisfaction. Meanwhile, model 2 calculates the significance coefficient value of organizational climate and infrastructure management on job satisfaction. The calculation process uses the SPSS 24 software with the results of calculation model 1 available in Table 1 and the results of calculation model 2 are available in Table 2.While the correlation coefficient of organizational climate on the variables of infrastructure, OCB and job satisfaction is in Table 3.

H1: Organizational climate has an indirect effect on job satisfaction through Organizational Citizenship Behavior The result of calculating the person correlation coefficient based on Table 1 shows the coefficient of the relationship between organizational climate and OCB of 0,581 which means positive and moderate. The path coefficient of organizational climate on OCB is 0.508 with a Sig value of 0.000 , which means that the Sig value is smaller than the probability value 0.05 or the value $0.05>$, it can be concluded that organizational climate has a significant effect on OCB. The indirect effect of organizational climate variables on teacher job satisfaction through OCB is $0.044+(0.508 * 0.619)=$ $0.044+0.314=0.358$. 
Table 1.The results of calculating the coefficient value of model 1

\begin{tabular}{|c|c|c|c|c|c|c|}
\hline & \multirow[t]{2}{*}{ Model } & \multicolumn{3}{|c|}{ Unstandardized Coefficients } & \multirow[t]{2}{*}{$\mathrm{t}$} & \multirow[t]{2}{*}{ Sig. } \\
\hline & & $\mathrm{B}$ & Std. Error & Beta & & \\
\hline \multirow{3}{*}{1} & (Constant) & 22.778 & 4.576 & & 4,977 & .000 \\
\hline & $\begin{array}{l}\text { Organizational } \\
\text { Climate }\end{array}$ & .534 & .052 & .508 & 10,204 & .000 \\
\hline & $\begin{array}{l}\text { Management of } \\
\text { Facilities and } \\
\text { Infrastructure }\end{array}$ & .209 & .042 & .250 & 5,032 & .000 \\
\hline
\end{tabular}

a. Dependent Variable: OCB

Table 2.The results of calculating the coefficient value of model 2

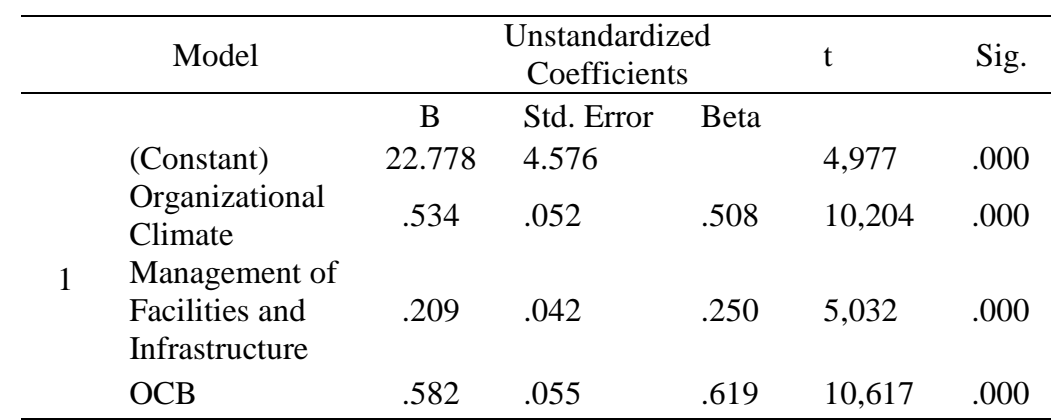

a. Dependent Variable: Job satisfaction

Table 3. The organizational climate correlation coefficient

\begin{tabular}{|c|c|c|c|c|c|}
\hline & & $\begin{array}{l}\text { Organizational } \\
\text { Climate }\end{array}$ & $\begin{array}{l}\text { Management of } \\
\text { Facilities and } \\
\text { Infrastructure }\end{array}$ & OCB & $\begin{array}{c}\text { Job } \\
\text { satisfaction }\end{array}$ \\
\hline Organizational & Pearson & 1 & $.293^{* *}$ & $.581^{* * *}$ & $.422^{* *}$ \\
\hline \multirow[t]{3}{*}{ Climate } & Correlation & & & & \\
\hline & Sig. (2-tailed) & & .000 & .000 & .000 \\
\hline & $\mathrm{N}$ & 270 & 270 & 270 & 270 \\
\hline
\end{tabular}

Various researches by experts have proven that organizational climate has a major influence on OCB, such as the results of previous studies which state: There is now evident that when the climate strength is weak of interest and the associated outcomes (e.g., Organizational Citizenship Behavior, accident rates) is also weak; thus, strength appears to have moderating effects on the interest of the relationship [22]. The conclusion of this research indicates that a strong positive organizational climate will create high OCB. The feeling of comfort that is felt by employees while at school will result in individuals feeling happy and working more eagerly to complete their work.

The results of other studies indicate that organizational climate which is the intervening variable of charismatic leadership has a positive and significant effect on OCB
[4]. Similar to this study, which places the OCB variable as an intervening variable on job satisfaction. The results obtained show that the contribution of OCB to teacher job satisfaction is $33.56 \%$ which is quite high when compared to the contribution of other independent variables [23].

Teachers who are employees of schools also have the same characteristics as employees who work in other agencies. Teachers who feel part of the school will be more loyal, willing to teach more, and help their fellow teachers because of the perceived organizational climate and the locus of teacher control [13]. Teachers who feel comfortable with the organizational climate at school will feel that the school is a second home, fellow teachers as siblings and students as their children [24]. 
H2: Organizational climate has an indirect effect on job satisfaction through Facility and Infrastructure Management

The result of calculating the person correlation coefficient based on Table 3 is the relationship between organizational climate and infrastructure management of 0.293 which means positive and weak. The infrastructure management path coefficient on OCB is 0.250 with a Sig value of 0.000 , which means that the Sig value is smaller than the probability value 0.05 or the value $0.05>0.000$, so it can be concluded that organizational climate has a direct and significant effect on facility management. The indirect effect of organizational climate variables on job satisfaction through management of facilities and infrastructure is $0.044+(0.293 * 0.063)=0.044+0.018$ $=0.062$.

When compared with the previous hypothesis testing, the results of the climate path coefficient through the management of facilities and infrastructure are smaller. Satisfaction occurs when individual needs are met and is related to the degree of likes and dislikes associated with employees; is a common attitude that employees have that is closely related to the rewards they believe they will receive after making a sacrifice [25].

Organizational climate is an overall "feeling" that is conveyed by the physical layout, the way participants interact, and the way members of the organization conduct themselves with customers or other outsiders [11]. This means that climate is how members feel at work which is influenced by the internal environment of the organization, influences their behavior, and is a characteristic of the organization. The internal environment is influenced by the management of facilities and infrastructure. Facilities and infrastructure during the workplace are one of the needs that must be met by a teacher at school [26]. If the created organizational climate is good, it will almost certainly have good management of facilities and infrastructure. Organizational climate can affect directly or indirectly the level of teacher job satisfaction [26]. So it is clear that the organizational climate has an indirect effect on the job satisfaction of VHS teachers.

\section{CONCLUSIONS}

Organizational climate has a more significant indirect contribution through OCB than through facility and infrastructure management. So there need to be efforts from PVHS managers, especially in DKI Jakarta to increase teacher job satisfaction through organizational climate. Efforts can be made by establishing and improving a conducive organizational climate so that teachers will feel happy to work while in school and feel part of the school.

\section{REFERENCES}

[1] J. L. Gibson, J. M. Ivancevich, J. James H. Donnelly, and R. Konopaske, Organizations Behavior, Structure, Processes. 2012

[2] N. Anderson, D. S. Ones, H. K. Sinangil, and C. Viswesvaran, Handbook of Industrial, Work \& Organizational Psychology, London: SAGE Publications, 2012.

[3] E. H. Schein, Organitzaional Culture and Leadership, 4th ed. San Francisco: Jossey-Bass, 2010.

[4] A. Khaskheli, Y. Jiang, S. A. Raza, M. A. Qureshi, K. A. Khan, J. Salam. Do CSR activities increase organizational citizenship behavior among employees? Mediating role of affective commitment and job satisfaction. Corporate Social Responsibility and Environmental Management, 27 (6) (2020) 2941-2955. DOI: https://doi.org/10.1002/csr.2013

[5] M. Kim, A. C. H. Kim, J. I. Newman, G. R. Ferris, P. L. Perrewé. The antecedents and consequences of positive organizational behavior: The role of psychological capital for promoting employee wellbeing in sport organizations. Sport Management Review, 22 (1) (2019) 108-125. DOI: https://doi.org /10.1016/j.smr.2018.04.003

[6] A. Ilyas, A. H. Khan, F. Zaid, M. Ali, A. Razzaq, W. A. Khan. Turnover Intention of Employees, Supervisor Support, and Open Innovation: The Role of Illegitimate Tasks. Journal of Open Innovation: Technology, Market, and Complexity, 6 (4) (2020) 128. DOI: https://doi.org/10.3390/joitmc6040128

[7] H. J. Jeon, K. A. Kwon, B. Walsh, M. M. Burnham, Y. J. Choi. Relations of early childhood education teachers' depressive symptoms, job-related stress, and professional motivation to beliefs about children and teaching practices. Early education and development, 30 (1) (2019) 131-144. DOI: https://doi .org/10.1080/10409289.2018.1539822

[8] R. Shanker, R. Bhanugopan, B. I. Van der Heijden, M. Farrell. Organizational climate for innovation and organizational performance: The mediating effect of innovative work behavior. Journal of vocational behavior, 100 (2017) 67-77. DOI: https://doi.org/10.1 016/j.jvb.2017.02.004

[9] W. Wikhamn. Innovation, sustainable HRM and customer satisfaction. International Journal of Hospitality Management, 76 (2019)102-110. DOI: https://doi.org/10.1016/j.ijhm.2018.04.009 
[10] X. Xie, Y. Jia, X. Meng, C. Li. Corporate social responsibility, customer satisfaction, and financial performance: The moderating effect of the institutional environment in two transition economies. Journal of Cleaner Production, 150 (2017) 26-39. DOI: https://doi.org/10.1016/j.jclepro.2017.02.192

[11] F. Luthans, Organizational Behavior An EvidenceBased Approach, 12th ed. New York: The McGrawHill Companies, Inc, 2011.

[12] D. G. Cotts, K. O. Roper, and R. P. Payant, The Facility Management Handbook, 3th ed. New York: AMACOM, 2010.

[13] C. Makate. Effective scaling of climate smart agriculture innovations in African smallholder agriculture: A review of approaches, policy and institutional strategy needs. Environmental science \& policy, 96 (2019) 37-51. DOI: https://doi.org/10.1016 /j.envsci.2019.01.014

[14] Prasetyono, H., Abdillah, A., Widiarto, T., \& Sriyono, H. (2018). Character-based economic learning implementation and teacher's reinforcement on student's affective competence in minimizing hoax. Cakrawala Pendidikan, 37(3), 426-435.

[15] Prasetyono, H., Kurniasari, D., \& Desnaranti, L. (2019). Evaluation of the implementation of Batik-skills training program. REiD (Research and Evaluation in Education), 5(2), 130-143. DOI : 10.21831/reid.v5i2.23 918.

[16] H. Prasetyono, A. Abdillah, T. Anita, A. Nurfarkhana, and A. Sefudin, Identification of the decline in learning outcomes in statistics courses using the chi-squared automatic interaction detection method. In Journal of Physics: Conference Series (Vol. 1490, No. 1, p. 012072). IOP Publishing, 2020, DOI: 10.1088/1742-6596/1490/1/012072.

[17] I. K. B. Sandika, S. Slamet, H. Usman. Partnership model of vocational education with the business sector in civil engineering expertise program of Vocational Secondary Schools. Jurnal Pendidikan Vokasi, 7 (3) (2017) 247-261. DOI: https://doi.org/10.21831/jpv. v7i3.9383

[18] A. Firdausi. Pengaruh Supervisi dan Kepercayaan Diri terhadap Kepuasan Kerja Guru SMKN di Jakarta Timur. SAP (Susunan Artikel Pendidikan), 2 (3) (2018). DOI: https://doi.org/10.30998/sap.v2i3.2453

[19] S. Safdar, S. Liu. The influence of justice on commitment of Pakistani bankers: Job satisfaction as mediator. International Journal of Public
Administration, 43 (14) (2020) 1183-1193. DOI: https://doi.org/10.1080/01900692.2019.1668408

[20] T. Wiyanto, M. Samani, S. Sugiyono. The developing teaching practice model as an effort to improve the quality of mechanical engineering vocational school teachers. Jurnal Pendidikan Vokasi, 7 (3) (2017) 349-363. DOI : https://doi.org/10.21831/jpv. v7i3.17923

[21] J. Kowal, A. Keplinger, J. Mäkiö. Organizational citizenship behavior of IT professionals: Lessons from Poland and Germany. Information Technology for Development, 25 (2) (2019) 227-249. DOI: https://doi.org/10.1080/02681102.2018.1508402

[22] J. A. Wagner and J. R. Hollenbeck, Organizational Behavior-Securing Competitive Advantage. New York: Routledge, 2010.

[23] G. A. F. Maulani, T. M. S. Mubarok. Analisis Pengaruh Teknologi Informasi Pada Iklim Organisasi Dan Dampaknya Terhadap Komitmen Organisasi Perguruan Tinggi Swasta. Journal Civics \& Social Studies, 4 (2) (2020) 12-24.

[24] J. Ramberg, S. Brolin Låftman, T. Åkerstedt, B. Modin. Teacher stress and students' school well-being: The case of upper secondary schools in Stockholm. Scandinavian Journal of Educational Research, 64 (6) (2020) 816-830. DOI: https://doi.org /10.1080/00313831.2019.1623308

[25] G. Blessing, M. Natter. Do mystery shoppers really predict customer satisfaction and sales performance? Journal of Retailing, 95 (3) (2019) 47-62. DOI: https://doi.org/10.1016/j.jretai.2019.04.001

[26] A. Toom, J. Pietarinen, T. Soini, K. Pyhältö. How does the learning environment in teacher education cultivate first year student teachers' sense of professional agency in the professional community?. Teaching and teacher education, 63 (2017) 126-136. DOI: https://doi.org/10.1016/j.tate.20 16.12.013 